\title{
Resource recovery from and management of wastewater in rural South Africa: Possibilities and practices
}

\author{
Masego Montwedi ${ }^{\mathrm{a}}$, Mujuru Munyaradzi ${ }^{\mathrm{a}}$, Luc Pinoy ${ }^{\mathrm{b}}$, Abhishek Dutta ${ }^{\mathrm{c}}$, David S. Ikumi ${ }^{\mathrm{d}, *}$ \\ Emilia Motoasca $^{\mathrm{e}}$, Bart Van der Bruggen ${ }^{\mathrm{f}}$
}

${ }^{a}$ University of Limpopo, Department of Water and Sanitation, Sovenga, South Africa

${ }^{\mathrm{b}} \mathrm{KU}$ Leuven, Department of Chemical Engineering Technology, Campus Ghent, Gent, Belgium

${ }^{\mathrm{c}}$ Izmir Institute of Technology, Department of Chemical Engineering, Gülbahçe Campus, Urla, Izmir, Turkey

${ }^{\mathrm{d}}$ University of Cape Town, Future Water Institute, Rondebosch, Cape Town, South Africa

${ }^{\mathrm{e}}$ Flemish Institute for Technological Research (VITO), EnergyVille, Genk, Belgium

${ }^{\mathrm{f}} \mathrm{KU}$ Leuven, Department of Chemical Engineering Technology, Leuven, Belgium

\section{A R T I C L E I N F O}

\section{Keywords:}

Resource recovery

Rural

Wastewater management

\begin{abstract}
A B S T R A C T
The continuous reduction in water resource availability is one of the major global societal challenges. Wastewater treatment plants (WWTP) play an important role in this, as they can provide water recovery. Furthermore, effective sanitation services lead to a significant reduction of health risks and protect the environment. However, WWTPs consume large amounts of energy to comply with discharge standards. At the same time, wastewater contains resources, which can be recovered for secondary uses, if treated properly. This is particularly useful for rural South Africa where challenges associated with water-based pollution, declining nutrients and water shortage, require a paradigm shift. This involves the transition of wastewater treatment plants into water, sanitation and resource (nutrients and energy) recovery facilities, leading further to social, economic and environmental sustainability. This process will involve the implementation of engineering tools for predictive modelling of the waste resource recovery systems. This review identifies the conceptual need for such a systematic shift from wastewater treatment to waste recovery facilities in rural South Africa. The targeted impact is to promote and help the uptake of the conversion of wastewater treatment systems into low cost and environmentally sustainable water and resource recovery facilities. Overall, the outlook is positive for the future use of these systems in South-Africa.
\end{abstract}

\section{Introduction}

Despite human progress as measured by various indices, billions of people globally still lack access to safe water and sanitation. Improved and sustainable infrastructure for water and sanitation is an important requirement for the reduction of human health risks and for environmental protection. Various reports indicate that achieving universal access for water and sanitation by 2030 (as envisaged in the Sustainable Development Goals ;SDGs) requires a technological revolution and material growth in the sector to progress at twice the current annual rate (UN Economic and Social Council 2019; [1]; UN report, 2019; [2]). A better management of water and sanitation services contributes in a significant way to reducing health risks and promoting environmental protection. There are significant well-established links between the quality of available water in a region, the sanitation methods and facilities, and human health. The lack of adequate sanitation would result in region-wide waste accumulation known to be detrimental to human and environmental health. Despite being a water-stressed country, South Africa (and majority of countries in the world), rely heavily on waterborne sanitation systems (with freshwater often used to flush toilets). Hence, the strategies to improve and promote sustainability of the sanitation systems are often linked to freshwater preservation (Govender et al., 2011; Government gazette, 2013).

It is estimated that about 150 megalitres of raw sewage have been leaking daily into rivers such as the Vaal River [2,3].

According to the 2018 Green Drop Report, there are 824 WWTPs in South Africa that are located in 152 municipalities and used to treat 6500 megalitres of wastewater daily. In 2013, these facilities received

\footnotetext{
* Corresponding author at: Future Water Institute, New Engineering Building, University of Cape Town, Rondebosch, 7701, Cape Town, South Africa.

E-mail address: david.ikumi@uct.ac.za (D.S. Ikumi).
} 
about 5120 megalitres countrywide, leaving $22.2 \%$ as excess capacity required for increased future wastewater treatment demands. In 2013, evaluations on the WWTPs in South Africa indicated that about 248 $(30.1 \%)$ of them were in a dire state needing urgent regulatory action. Only about 60 or $7 \%$ of WWTPs passed the Green Drop status so as to receive certification [2].

Although effluent quality is the most important objective for WWTPs, they could be used for more than just wastewater purification and achieve higher sustainability by lowering their use of nonrenewable energy sources and increasing their resource recovery potential (Lundin et al., 2000). Improvement in resource recovery potential could be achieved through strategies such as (i) onsite energy generation (e.g., conversion of wastewater organics to electricity, heat or biofuel), the recycle of nutrients (e.g. fertilizer production) and reuse of effluent water (e.g., further purification of WWTP effluents to augment the potable water supply) [4]. Research to evaluate the various methods of resource recovery in WWTPs has been mostly carried out in the US, Canada, Japan and some European countries. Most of these studies are in the form of case studies, which are usually specific to the system capacity (Verstraete et al., 2009; [4]), the given organic and nutrient loading rates and the local conditions. There have been very few studies that looked at integrated resource recovery in the WWTPs (McCarty et al., 2011; Slater, 2009; Verstraete et al., 2009; [4]).

This review focuses on the challenges associated with water-based pollution, declining nutrients and water shortage, which necessitate the transition of wastewater treatment plants into water and resource (nutrients and energy) recovery facilities (WRRFs), for more socioeconomically and environmentally sustainable systems. The review is focused towards this paradigm shift in rural South Africa.

The recently started South Initiative project WaRe-SimPLE (conversion of waste treatment to WRRFs in Limpopo, using simulation-based engineering tools) financed by VLIR-UOS (Flemish Interuniversity Council) focuses on the use of open-source simulation-based engineering tools to support the accelerated conversion of wastewater treatment facilities into resource recovery facilities. The project aims at capacity development, related to modelling and simulation of recovery facilities, in terms of knowledge building at University of Limpopo and on longer term to develop regional South African expertise in order to assist stakeholders in the development and management of such novel water treatment systems. This review thus aims at pointing out the state-of-the art related to this subject in the context of South Africa, with a focus on the rural regions.

\section{Wastewater treatment and sanitation}

About 180,000 children ( $<5$ years of age) die every year (ca. 500 children death per day) in sub-Saharan Africa because of diarrhoeal diseases related to inadequate water, sanitation and hygiene [5]. The population in sub-Saharan African countries has almost doubled in the last 25 years, but access of the Africans to sanitation and water resources has improved minimally, leaving millions without these services. In the countries with the best water coverage rates, as many as one fourth of the population lacks adequate sanitation [5]. South Africa has a history of separate and racialised development, which resulted in many rural and black areas having no access to basic water and sanitation services. However, a dedicated Basic Services Development Programme (BSDP) started in 1994 is dealing with these historic backlogs with the specific target [6] that all people in South Africa should have access to functioning basic water supply facilities and basic sanitation facilities by 2014. This has so far been partially achieved and it was running together with the Sustainable Development Goals (SDGs), which were the successors to the basic water and sanitation targets. The [7] in 2012, Rio de Janeiro, resulted in a set of SDGs to build on the achievements of the MDGs, included into a global development framework beyond 2015. In 2014, the UN General Assembly Open Working Group (OWG) came up with 17 goals for the General Assembly's approval in September 2015, and these became the new SDGs and the global development agenda spanning from 2015-2030. Water and sanitation targets are part of Goal 6 of an SDG that advocates for availability and sustainable management of water and sanitation services for all.

Effective sanitation services (which entail adequate facilities that collect and treat municipal wastewater effectively) lead to significant reduction of health risks and protect the environment. Effective sanitation services entail adequate facilities that collect and treat municipal wastewater effectively, and thus making sure human dignity is secured and health of the people is protected. Due to a myriad of problems (e.g., huge amounts of raw sewage have been spilling into one of the major rivers, the Vaal River; [8]), rural South Africa's sanitation and wastewater treatment systems are largely malfunctioning, leading to some of the population without access to dignified and safe sanitation facilities. The households that have access to sanitation services such as conventional flush toilets connected to a public sewerage system or other functioning systems (e.g., a septic tank or a pit toilet with a ventilation pipe) are currently at about $82.2 \%$, with about $3.1 \%$ without any sanitation facilities [2]. Most provinces in South Africa perform close to the national average in terms of provision of expected sanitation services, but the rural provinces of Limpopo and Mpumalanga are still far behind the rest. Overall, the survey carried out in 2017 indicates a significant $(20 \%)$ improvement since the survey that was carried out in 2002, but do not show the state of the current available facilities and infrastructure for sanitation and wastewater treatment. The South African Institution of Civil Engineers [1] noted that, in urban areas of South Africa, the sanitation infrastructure (including wastewater systems) is acceptable (but under extreme stress) in urban areas, while in rural areas where the majority of black people stay, the systems are collapsing and could potentially expose the public to health and safety hazards.

As mentioned in earlier, the South African government developed the Green Drop Programme in 2008, which was used to provide an indication of the performance of wastewater treatment systems within the various municipalities. This programme facilitates compliance with nationally set regulatory objectives, and in the process ensuring that the wastewater treatment systems meet minimum required standards for protection of human and environmental health. The project has two elements: (i) Evaluation of the wastewater value chain (including sewerage reticulation, pumping requirements, wastewater treatment plant and effluent discharge to receiving water bodies), (ii) The cumulative risk assessment (mainly focuses on wastewater treatment) [2]. According to the Green Drop Report of 2013 [9], only 60 (7\%) of South Africa's 824 wastewater treatment facilities received clear Green Drop Certification. With regard to pollution loads, phosphorus (P) and nitrogen $(\mathrm{N})$ compounds are the two primary causes of eutrophication of surface waters. In an effort to combat this problem, the South African government department involved with Water \& Sanitation is setting more stringent effluent requirements via treatment plant licensing for both inland and coastal regions. At the same time, many of South Africa's municipal treatment plants are approaching or have reached their design load capacity or are in fact overloaded. Many of these overloaded treatment systems have nutrient removal constraints. Most wastewater treatment and sanitation works do not consider the return of sludge liquors back to the main plant for further treatment (nor do they have any side stream treatment processes/ technologies). Moreover, some of the plants that do recycle their dewatering liquors, do not have the required capacity to deal with these additional loads and flows [10]. Unsustainable measures such as the dosing of costly chemicals (typically metal salts) for phosphate removal are typically applied at overloaded plants. The capital and operational costs for municipal wastewater treatment plants run into billions of Rand per annum. There is therefore an acute need to look at optimisation measures within treatment systems to reduce the nutrient loads on overloaded treatment plants in rural South Africa.

Although the Green Drop figures are somewhat of a shocker in terms 
of dysfunctionality of a large number of wastewater treatment works, global indicators suggest that South Africa fares better at wastewater treatment than it does in access to water and sanitation. The Environmental Performance Index [11] (EPI; provides performance indicators for environmental health and ecosystem vitality) out of 180 countries ranked in the EPI, South Africa is at position 50 for wastewater treatment and 13 for sanitation access. Various studies [1,10,9] report major factors responsible for the failing state of wastewater treatment facilities in South Africa and other such countries to go beyond lack of technical expertise for good design and system operation and to include corruption, insufficient allocation of funds and poor compliance monitoring, among others. Such compromised wastewater treatment works release poor quality effluent water into various surface water bodies, leading to eutrophication of these water bodies [12]

\section{Wastewater management in rural South Africa}

Water pollution, and in particular, eutrophication of South Africa's scarce water resources is a major concern due to the threat it poses to the nation's water security. One of the major point sources of pollution loads on surface water resources are effluent streams from municipal wastewater treatment works.

Historically, management of wastewater treatment systems has been characterised by a stepwise progression from solving sanitation problems (this was the main focus at early phases of 20th Century) to the avoidance of eutrophication in receiving water bodies and nutrient recovery/recycling (has been emphasized over the past 10 years) [13]. However, there are still many cities in developing countries with the problem of polluted water resources due to discharges of domestic and industrial wastes into receiving water bodies ([13,14]; Chowdhury \& Mete., 2018).

In many developing countries a large portion of the wastewater is solely taken through primary treatment and discharged without going through the required biological processes for removal of dissolved biodegradable organics and nutrients. Although some level of wastewater treatment is observed in South Africa, poor operation and maintenance of the wastewater treatment facilities is the reason for discharge of poor quality effluents to various water bodies quality (Momba et al., 2006; [14]). Therefore, a functional and sustainable wastewater management scheme is necessary and should begin at the household level and is largely dependent on the human component, especially around the degree of acceptability for reuse of resources recovered from the waste [15]. Whilst highly efficient technologies are available, Nhapi and Gijzen [13] outline three steps towards a functional wastewater management scheme (i) minimization of wastewater generation through drastic reduction in consumption of water and generation of waste (ii) direct treatment and optimal recycling of water and of nutrients at the smallest possible level (e.g., on-plot application) (iii) intervention to enhance the self-purification capacity of receiving water bodies. An example showcasing the implementation of this was the construction of six inlets and four outlet doors at the heavily polluted Bocana de la Virgen Bay, in Cartagena, Colombia, which allowed for the control of water inflows and effluent outflows by tidal pressure (Moor et al., 2002).

Conventional wastewater treatment techniques (e.g., activated sludge for organic and nutrient removal, adsorption for removal of heavy metals, ozonation for removal of pathogens, etc) have been traditionally applied to remove pollutants [16]. All the methods and technologies have their own disadvantages such as consisting of complex processes and require large land areas, and they can carry high operation costs. According to Amoatey and Bani (2016), the biggest challenges of wastewater management are infrastructure, pollution of water sources, choice of appropriate technology, sludge production and reuse. Moreover, wastewater management though not technically difficult can sometimes be faced with socio-economic challenges (Amoatey and Bani, 2016). South Africa is still confronted with huge socio-economic challenges due to past political and socio-economic situation of the country. Despite the progress and general advancement in urban regions, the rural areas are less developed, with poor water and sanitation facilities. Diseases occasioned by usage of polluted water still have huge economic and social consequences for the people in rural regions with traditional communities heavily relying on this polluted water for drinking, agriculture and sometimes for small businesses, like local restaurants, recreation facilities, processing of crops, production of food, etc. The lack of adequate education together with reduced financial capabilities with respect to implementation of water and sanitation facilities is still a challenge for many traditional rural communities.

Therefore, considerations regarding the appropriateness of technologies and other factors should be rooted in, firstly, if the technology (whether centralised or decentralised) is a priority for environmental and human health. Secondly, the technology should be low-costing, robust and require the least input of energy. Thirdly, the technology should have low complexity, easily maintained by the local community and should be able to recover resources. Lastly, the technology should be easy to upgrade with increased user demand or stricter effluent quality standards (Yadava and Singh, 2003).

\subsection{Energy}

According to SEA (2017) water supply and wastewater treatment systems in South Africa account for $25 \%$ of all municipal energy consumptions and present the greatest energy saving opportunity. Energy (electricity) cost is the most significant cost in wastewater treatment plants in First World countries, as can be seen in Fig. 1, and with the electricity cost steadily increasing in South Africa, electricity costs are equally steadily becoming the most expensive part of running a wastewater treatment plant [17].

Musvoto \& Ikumi [18] agreed with Scheepers \& van de Merwe-Botha [17] as they also noticed that no significant focus had been placed on mitigating electricity cost increases at WRRFs in South Africa as these costs were low in the past. Moreover, it is pointed out that municipalities need to consider energy management as an intrinsic part of wastewater operations in order to remain sustainable, as ESKOM (Elektrisiteitsvoorsieningskommissie, Government of South Africa) electricity rates are predicted to continue to sharply increase in the foreseeable future.

According to Scheepers \& van der Merwe-Botha [17], above $50 \%$ of the energy usage in the South African water sector is from the treatment of wastewater and aeration uses the bulk of this energy (50-75\% - see Fig. 2). Various research studies in China ([19,20,21] to name a few) have made conclusions that agree with a report from 600 WWTPs elsewhere [22].

Various studies (Taricska et al., 2009, Liu and Liptak, 1997) have been done to determine the feasibility of energy recovery from waste treatment systems in South Africa. Burton et al. [23] reported about

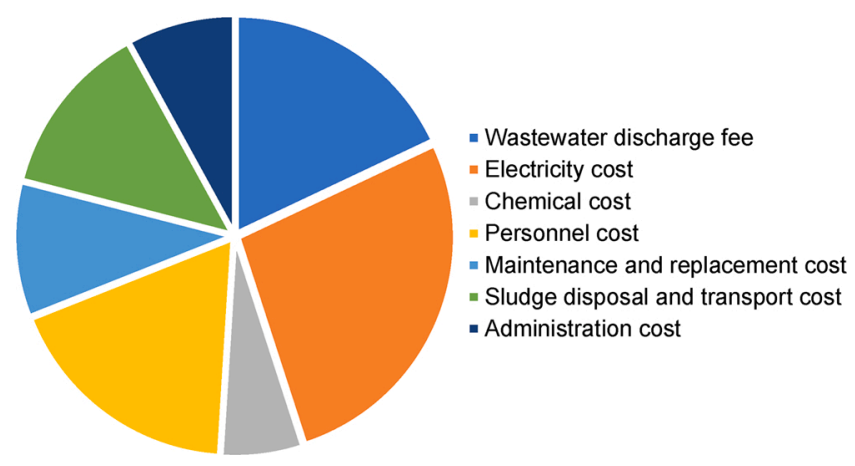

Fig. 1. Running cost of typical wastewater treatment plant [17]. The wastewater discharge fee can be thought of as similar to the Waste Discharge Charge System Levy in South Africa. 


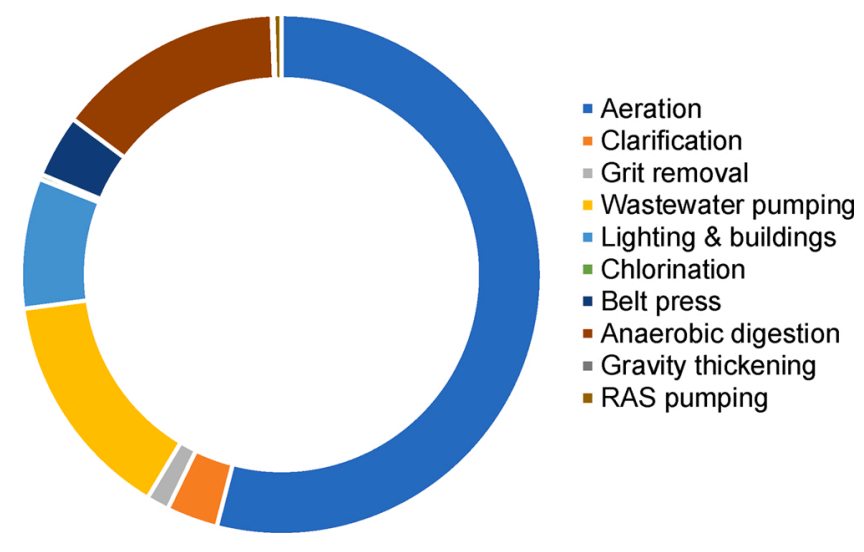

Fig. 2. Shares in electricity requirements for a typical activated sludge wastewater treatment plant (adapted from [18]).

municipal wastewater treatment only plants (WWTPs) in South Africa with a combined energy potential of $1134 \mathrm{MJ} / \mathrm{s}$ were operating at $100 \%$ capacity. An estimated 10,000 MWh can be recovered from the domestic and industrial wastewater sludge generated by a population of 48.5 million in the whole of South Africa. According to Stafford et al. [24] the population generates $9.7 \times 10^{9} \mathrm{~L} /$ day of wastewater with a COD of 0.86 $\mathrm{g}$ COD/L), which represented about $7 \%$ of Eskom electrical power supply in 2009 [23].The data generated in a case study by Swartz et al. [25] showed that a plant treating $450 \mathrm{ML} / \mathrm{d}$ requiring 8.0 MW energy, has the potential to generate 4.4 MW electrical energy. Ekama [26], using a mass balanced steady state model determined the energy recoverable from anaerobic digestion (using $15.1 \mathrm{kWh} / \mathrm{kg} \mathrm{CH}$ and a thermal efficiency of $45 \%$ and energy consumption to heat the $\mathrm{AD}$ at 30 $\mathrm{W} / \mathrm{m}$ [27] AD volume for a plant treating $15 \mathrm{ML} / \mathrm{d}$ of sewage (with 750 $\mathrm{mg}$ COD/L organic strength), with pumping and aeration $(2.5 \mathrm{~kg}$ $\mathrm{O} / \mathrm{kWh}$ )) energy requirements for the energy consumption values. From this study, it is estimated that about $20 \%$ of the energy used at the WWTP is recovered from the AD process. This value is less than that obtained by Swartz et al. [25] where potentially about $50 \%$ of energy savings are noted from the overall adjustments in control methods, operational routines and maintenance for South African plants. Despite the energy recoverable being less than the consumed energy, the study by Swartz et al. [25] encourages the implementation of biogas energy production projects. In support, Gu et al. [28] notes that WWTPs which have pre-settling and a digester have the potential to consume $40 \%$ less energy on average compared to one without these features. Following the recommendation of Swartz et al. [25], subsequent studies [29,30] were conducted focusing on biogas generation from anaerobic digestion waste sludge. One of these studies concluded that, application of biogas to energy is economically viable for large WRRFs, with influent flows above $15 \mathrm{ML} / \mathrm{d}$, and would require long term investment, with viable returns possible over a 7-10-year period [29]. Moreover, although $71 \%$ of WWTPs in South Africa have the capacity to generate energy, if advanced anaerobic digestion with combined heat and power (CHP) generation is implemented [29], opportunities for co-digestion of municipal sewage sludge and other biodegradable organics, such as food waste, should be explored [31]. There are various disposal routes, but anaerobic digestion appears to be a popular sludge management alternative because of its ability to generate bioenergy by reducing sludge volumes to be disposed of [32]. Further studies towards optimised energy recovery include investigations by Mills et al. [33]. In this study, Life Cycle Assessment (LCA) was used to evaluate the energy used and the energy that can be recovered from WWTPs products as a measure for their environmental and economic impacts. Five energy recovery configurations were considered, namely (i) conventional anaerobic digestion with Combined Heat and Power (CHP), (ii) Thermal Hydrolysis Process (THP) anaerobic digestion with CHP, (iii) biomethane grid injection from THP anaerobic digestion, (iv) THP anaerobic digestion with CHP followed by drying of the digested sludge to be used for the production of solid fuel, and (v) drying, followed by pyrolysis of THP anaerobically digested sludge and the use of biogas and pyrolysis gas in CHP. In this study, various factors that were both environmentally friendly and economically advantageous were considered to determine the process. The impacts deemed important for environmental analysis included (i) GWP - Global Warming Potential (excluding biogenic) ( $\mathrm{kgCO}_{2}$-Equiv.), (ii) POCP - Photo Ozone Creation Potential (kg Ethene - Equiv.), (iii) EP - Eutrophication Potential (kg Phosphate - Equiv.), (iv) AP - Acidification $\left(\mathrm{kgSO}_{2}\right.$ - Equiv.), (v) ADP element - Abiotic Depletion (elements kg Sb - Equiv.) and (vi) ADP fossil - Abiotic Depletion (fossil MJ). For economic assessment the capital costs were calculated for each scenario according to common chemical engineering techniques presented by [34]), while the operating costs were calculated as shown in the work of Mills [35] Options (iv) and (v) performed the best with option (iv) being determined to be the most environmentally and economically viable. It is also determined that despite the financial appeal of bio-methane production for energy, it is not currently environment friendly, however Mills et al. [33] suggests that as the electricity grid is decarbonised, the production of biomethane for injection in the electricity grid becomes more environmentally sustainable.

All the above strategies and efforts to save energy at WWTPs are important, but these efforts should not be at the expense of effluent quality and human and environmental health. The investigation by Svardal and Kroiss [36] indicates that treated water has a far greater value as a potential fresh water source than the energy consumed in its treatment or the relatively small quantities of energy that can be recovered from it [37]. Further, in a comparative study by Ekama [38] it was shown that the carbon emissions by WWTPs (around $20 \mathrm{~g}$ $\mathrm{CO}_{2}-\mathrm{C}$ /person equivalent) are negligible relative to other human activities. For example $20 \mathrm{~g}$ is $12 \%$ of the $180 \mathrm{~g} \mathrm{CO}_{2}-\mathrm{C} /$ (person.d) exhaled by a person with a $6300 \mathrm{~kJ} / \mathrm{d}$ diet $50 \%$ of the $40 \mathrm{~g} \mathrm{CO}_{2}$-C/(person.d) generated to treat the wastewater at fossil fuel power stations, $1 \%$ of the $2000 \mathrm{~g} \mathrm{CO}_{2}-\mathrm{C} /$ (person.d) produced by motor vehicle driving at 30 $\mathrm{km} /$ (person.d), $0.2 \%$ of the $10,000 \mathrm{~g} \mathrm{CO}_{2}-\mathrm{C} /$ (person.d) generated at fossil fuel power plants for utilisation as domestic electricity at $27 \mathrm{kWh}$ / (person.d) or $1.1 \mathrm{~kW} /$ person or $0.044 \%$ of the $45,000 \mathrm{~g} \mathrm{CO} 2-\mathrm{C} /$ (person. d) for total power consumption at $5 \mathrm{~kW} /$ person [37].

\subsection{Water}

Since South Africa is currently considered a chronic water scarce country (500-1000 $\mathrm{m}^{3}$ /person/annum) and moving towards absolute water scarcity $\left(500 \mathrm{~m}^{3}\right.$ /person/annum), it would be advantageous to implement some form of wastewater re-use to assist in preventing a drought [39]. Nationally, effluent is most commonly simply discharged to a water body, with only $8.3 \%$ of 824 WWTPs complying with effluent regulations [40]. Globally, many nations presently recycle less than 10 $\%$ of their total wastewater effluent [41]; the most common form of wastewater reuse is through agriculture [42]. Considering increasing water scarcity and the cost associated with obtaining potable water through alternative means (such as desalination) it would be more profitable to at least apply wastewater effluent for agricultural reuse in order to decrease the amount of potable water being used. Other ways of water reuse include industrial reuse, urban reuse, and indirect and direct potable reuse. The different types of water reuse would have different water quality standards to be met. However, public perception and the potential health hazards associated with the reuse would suggest starting with non-potable reuse applications that do not include the use of reclaimed water on crops meant for food production. This could assist in alleviating the stress on potable water until public perception can be improved with time and all health hazards mitigated. Importantly, the labels implemented are significant towards perception, as farmers are more willing to use water for irrigation if it is labelled as recycled water instead of treated wastewater [43]. Other factors to consider in 
wastewater reclamation include the feasibilities based on location of the wastewater treatment facility (regulations vary depending on locations, e.g., coastal versus inland; [44]) and the presence of toxic contaminants (generally due to industrial effluents), heavy metals, pathogens or micropollutants (such as pharmaceuticals and hormones). The removal of these compounds is becoming increasingly important for the environment sustainability and human health, because of the effects they have on reproductive systems, especially for water scarce regions such as South Africa that are beginning to rely on treated wastewater reclamation for potable reuse [45].

\subsection{Nutrients}

With the rising demand for food supply, there is an increase in demand for nutrients (including nitrogen $(\mathrm{N})$ and phosphorus $(\mathrm{P})$ ). Both $\mathrm{N}$ (required in reactive forms, i.e., ammonium, nitrate and nitrite) and $\mathrm{P}$ are usually present in municipal wastewaters and can be recovered in the waste treatment processes to promote their use in food production (plant growth), while ensuring that the WWTP effluents discharged to water bodies do not result in eutrophication. The $\mathrm{P}$ is predominantly obtained from phosphorus rock, a non-renewable, irreplaceable resource that may end up depleted in approximately $50-100$ years [41, $46,47]$. Moreover, the phosphorus rock is geographically concentrated in few countries, requiring other countries to import most of their fertilizers. This significantly impacts the cost of food production and could create economic and political risks [41]. Various studies have been done to explore the opportunity for nutrient recovery from wastewater; via generation of $\mathrm{N}$ and P-rich sludge as fertilizers or soil conditioner, or recovery of $\mathrm{N}$ and $\mathrm{P}$ in the form of struvite (Ma et al. (2015). Vanrolleghem and Vaneeckhaute [48] have further discussed nutrient recovery from WRRFs to involve extraction techniques of (i) chemical crystallisation, (ii) gas stripping and absorption, (iii) acidic air scrubbing, (iv) membrane separation and (v) biomass production and harvest.

Other technologies for nutrient recovery include the use of aquatic biomass such as microalgae and floating macrophytes for uptake of nutrients. For example, the harvested microalgae could then be used for livestock feed, biofuel production and fertilizer [49]. However, although these methods are cost efficient, there are some challenges experienced in harvesting the biomass for full scale nutrient accumulation [50]. Compared to these biological methods, chemical processes that allow for the recovery of nutrients in concentrated forms, such as controlled precipitation of struvite $\left(\mathrm{MgNH}_{4} \mathrm{PO}_{4} \cdot 6 \mathrm{H}_{2} \mathrm{O}\right)$, have recently been more desirable due to the wider range of options for eventual reuse with lower risk of pathogens, easier transportation and proven energy efficiency (Theregodwa et al., 2019;[50]).

Table 1 shows the potential amount of carbon (C), nitrogen $(\mathrm{N})$ and phosphorus (P) produced in wastewater effluent in South Africa per year [51]. This gives an indication of the potential products that could be

\section{Table 1}

Annual production of C, N and P from the effluent of South African industries (adapted from [121]). The industries not listed in the table include distillery, edible oil, soft drinks, fishery and winery as their contribution was not found to be significant.

\begin{tabular}{lllll}
\hline $\begin{array}{l}\text { Industry } \\
\text { sector }\end{array}$ & $\begin{array}{l}\text { M } \ell \text { effluent } \\
\text { per year }\end{array}$ & $\begin{array}{l}\text { Estimated ton } \\
\mathrm{C} / \text { year }\end{array}$ & $\begin{array}{l}\text { Estimated ton } \\
\mathrm{N} / \text { year }\end{array}$ & $\begin{array}{l}\text { Estimated ton } \\
\mathrm{P} / \text { year }\end{array}$ \\
\hline $\begin{array}{l}\text { Municipality } \\
\text { Abattoir }\end{array}$ & $1,825,000$ & $4,653,750$ & 118,625 & 28,288 \\
$\quad$ (poultry) & 5400 & 71,280 & 945 & 308 \\
$\begin{array}{l}\text { Abattoir (red } \\
\text { meat) }\end{array}$ & 8188 & 139,057 & 101 & - \\
$\begin{array}{l}\text { Dairy } \\
\text { Brewing }\end{array}$ & 86,393 & 3.9 million & 30,238 & 3456 \\
Canning & 8334 & 100,008 & 438 & 250 \\
Pulp \& Paper & 1074 & 11,599 & - & - \\
Petroleum & 339,300 & 967,005 & 3068 & 443 \\
Textiles & 77,380 & 1.83 million & 3691 & 101 \\
\hline
\end{tabular}

recovered to achieve a greater environmental and potentially economic benefit. In many countries, including South Africa, the recovered phosphorus prices (i.e., in forms such as struvite) cannot currently compete with mined phosphorus prices, however, it becomes more feasible in the long term when one accounts for the resources (energy, nitrogen, metals, minerals and water) that can be recovered concurrently with phosphorus [41].

\section{Integrated resource recovery}

The need for improved and sustainable infrastructure in the water and sanitation sector continues to intensify as the global population under water stressed conditions increases [13,52]. In many regions, these conditions are a result of continued mismanagement of water resources (i.e., with improvements needed towards decision making in the design, operation and maintenance of infrastructure used for provision of socially, economically and environmentally sustainable water and sanitation systems), because faults in the infrastructure (e.g., malfunctioning wastewater treatment plants and pipe leakages in the water and sewage reticulation networks due to under-investment in their maintenance and refurbishment) remain hidden, hence public outcry is often delayed until when too late. However, some intervention in the form of intensifying water pollution prevention programmes, introduction of technologies for affordable sanitation for industrial and domestic wastewater treatment, mitigation of the effects of groundwater contamination, monitoring systems and effective legal frameworks, is required to avoid the potential water shortage and city-wide wastewater accumulation that would result in threats to human health and environmental wellbeing [6]. Integrated Resource Recovery is a concept that is rooted in recovering valuable resources from waste. The emphasis of this concept lies on its ability to transform waste into resources through composting, recycling and bio digestion, thereby diverting municipal solid waste from landfills or open dump sites. The major focus of this concept is on collection and processing of waste and sale of the resources generated. Organic and inorganic waste, which typically comes from both private and public sectors respectively, serve as the inlet source of resource recovery [53]. Fig. 3 depicts the systematic interconnectedness that exist within various processes that are involved in the integrated resource recovery related to wastewater. There are other factors that influence the success of resource recovery and those factors include; stakeholders that range from wastewater treatment plant managers to investors and engineering modelling tools that would simulate the efficient running of the process and optimum production of energy. The capturing and reuse of nutrients, energy and water collected at wastewater treatment plants come with economic, environmental and social benefits. Methane-rich biogas can be utilized for heating buildings, and for plant processes. In addition, greenhouse gases causing climate change can be reduced through treating the organic fraction of waste, and inevitably there will be reduction of diseases from untreated waste $[54,55]$.

In the context of wastewater treatment, integrated resource recovery involves connecting the wastewater treatment plants to unit operations beyond the fence of the WWTP, such that the source of pollutants to the plant and the fate of the products generated by the plant are included in the management and planning of the entire system for maximum benefit from the recovery of resources. Hence, the decisions made in the design and optimised operation of the WWTP and the connected unit operations (i.e., the entire system) are influenced by the extent of environmental, social and economic progress that the recovered resources would promote. The decision-making processes that would allow for the transformation of wastewater treatment systems to water and resource recovery facilities that are socially inclusive, cost effective and environmentally sustainable, involves collaboration between a network of stakeholders including consulting engineers, municipal workers, researchers, and public health specialists. Mathematical models, primarily based on the Activated Sludge Model (ASM), could be used as tools in 


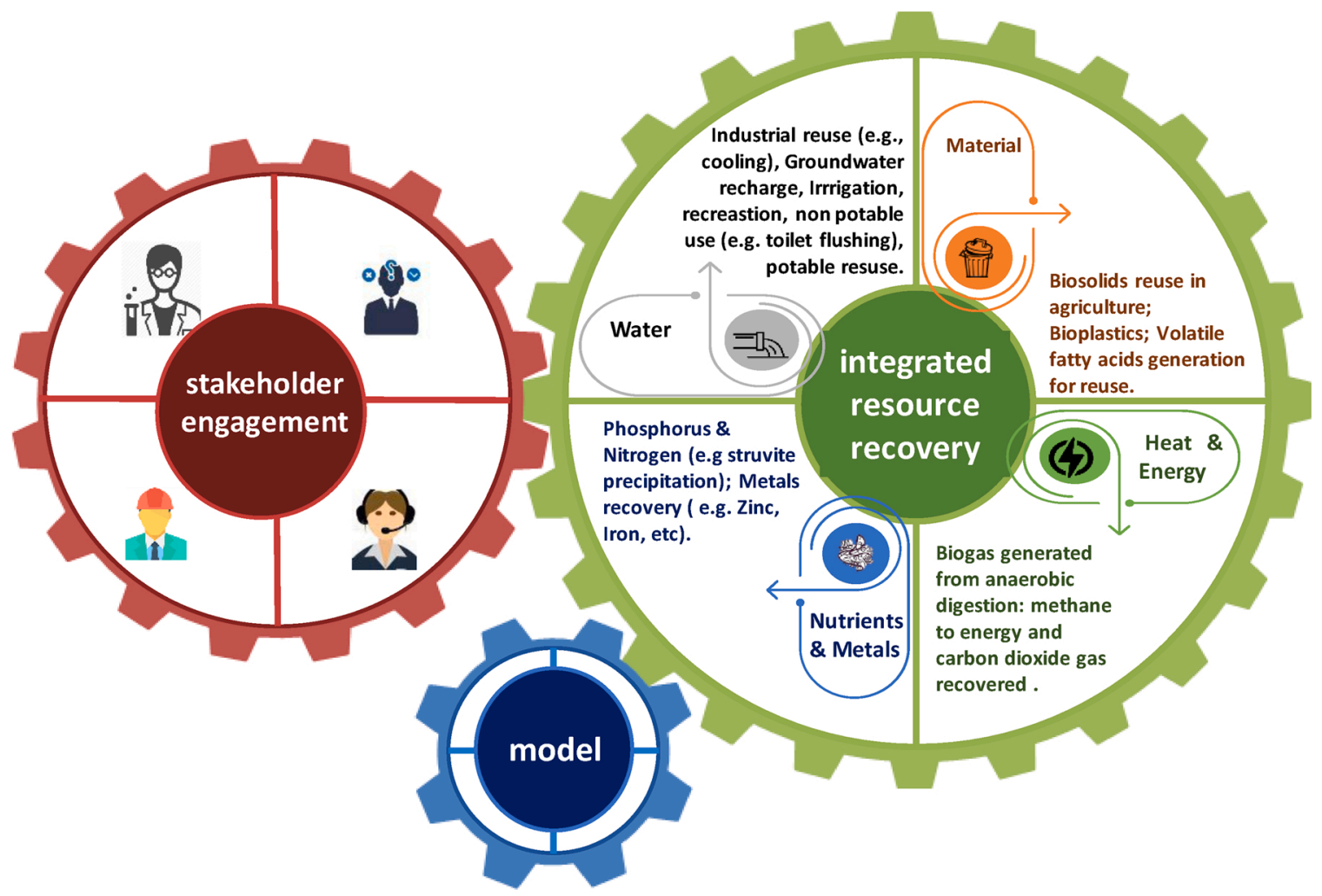

Fig. 3. A conceptual framework for the integrated resource recovery based on wastewater.

such instances to integrate the ideas that define strategy evaluation for recovery systems. However, since WRRFs are often operated under relatively stable conditions and not with the same dynamics as WTTPs, there is less need for dynamic models and stoichiometric models would be adequate enough. Dynamic modelling would be still useful for optimization, especially when accounting for the interaction of the recovery process with the rest of the wastewater treatment unit processes [56]. A detailed list of such existing modelling strategies can be found in the following section.

Originally, the main concern behind the design and optimised operation of wastewater treatment systems was the struggle to meet the strict effluent discharge regulations required to protect regions' water resources ([57]; Henze et al., 2008). Currently, there are global shifting paradigms (e.g., conventional treatment of wastewater towards a more productive recovery of resources [58] and from water-stressed cities to water-sensitive regions [59] that have necessitated re-thinking the incorporation of resources (mainly, water, nutrients $(\mathrm{N})$ and $(\mathrm{P})$ and energy) recovery in waste treatment processes. To ensure that solutions towards achievement of such sustainable water and resource recovery facilities (WRRFs) are holistic and based on scientifically sound principles, tools (such as mathematical models) that provide expert information on the entire waste treatment systems can be used in their strategic evaluation. A list of potential products recovered from sewage municipal

Table 2

Motivation for resource recovery and the related activities where they can be used (adapted from [60]).

\begin{tabular}{lll}
\hline Motivation & Activity & Innovation \\
\hline & Water reuse & Industrial cooling \\
& Materials recovery & Landscape irrigation \\
& Biosolids reuse & N, P compounds \\
Increased revenues, Reduced costs & Energy generation & Bioplastics, Solid fuels, \\
& & Photovoltaics \\
& Energy recovery & Methane Hydrogen \\
& & Heat recovery \\
\hline
\end{tabular}

water (adopted from [60]) can be found in Table 2.

Apart from what is mentioned in the table, a key benefit would be the lowered competition for freshwater, with the consideration of treated wastewater as an alternative source of water for use in different activities. According to Qin et al. [61], about $80 \%$ of the needed freshwater can be generated via optimised reuse strategies for treated wastewater [61]. Examples of popular reuse strategies for treated effluents from WWTPs include application for agriculture, use towards landscape irrigation and also various applications in the industrial sector ([62]; [63]).

In order to accomplish successful, economically and environmentally feasible resource recovery from wastewater, communication and collaboration will be required across disciplines that do not usually require dialogue between them. This includes farmers, public health officials, municipal and waste managers, water utilities, regulatory agencies, environmental authorities, planners and developers. Further, solutions to technological barriers are required [28]. Burton et al. [23] identifies the following technological barriers: (i) Technologies that have been implemented internationally but has not yet been implemented in South Africa and has its implementation hampered due to a lack of demonstration, (ii) The reliability of new technologies needs to be proven with time before it is trusted, (iii) New designs are not always appropriate for the local context of a developing country due to operation and maintenance requirements, (iv) There is a lack of human resources required to fulfil maintenance requirements. Table 3 lists the possible sources of resource recovery (effluent water reuse, sludge disposal and mineral precipitates nitrogen recovery) and the various environmental and other considerations.

Biogas can be used for energy supply (heating, hot water, supply warm air for drying). The use of biogas (see Table 4) as an energy supply does not add to carbon dioxide emissions into the atmosphere. The exhaust is clean and does not produce particles or odours. Furthermore, the use of biogas instead of fossil fuels makes industrial applications more sustainable [72]. The upgraded biogas (biomethane stripped mainly from hydrogen sulphide and carbon dioxide) increases the energy content of the gas. This improved gas can be used as fuel for various 
Table 3

Possible sources of resource recovery (effluent water reuse, sludge disposal and mineral precipitates nitrogen recovery) and the various environmental and related considerations (adapted from [122]).

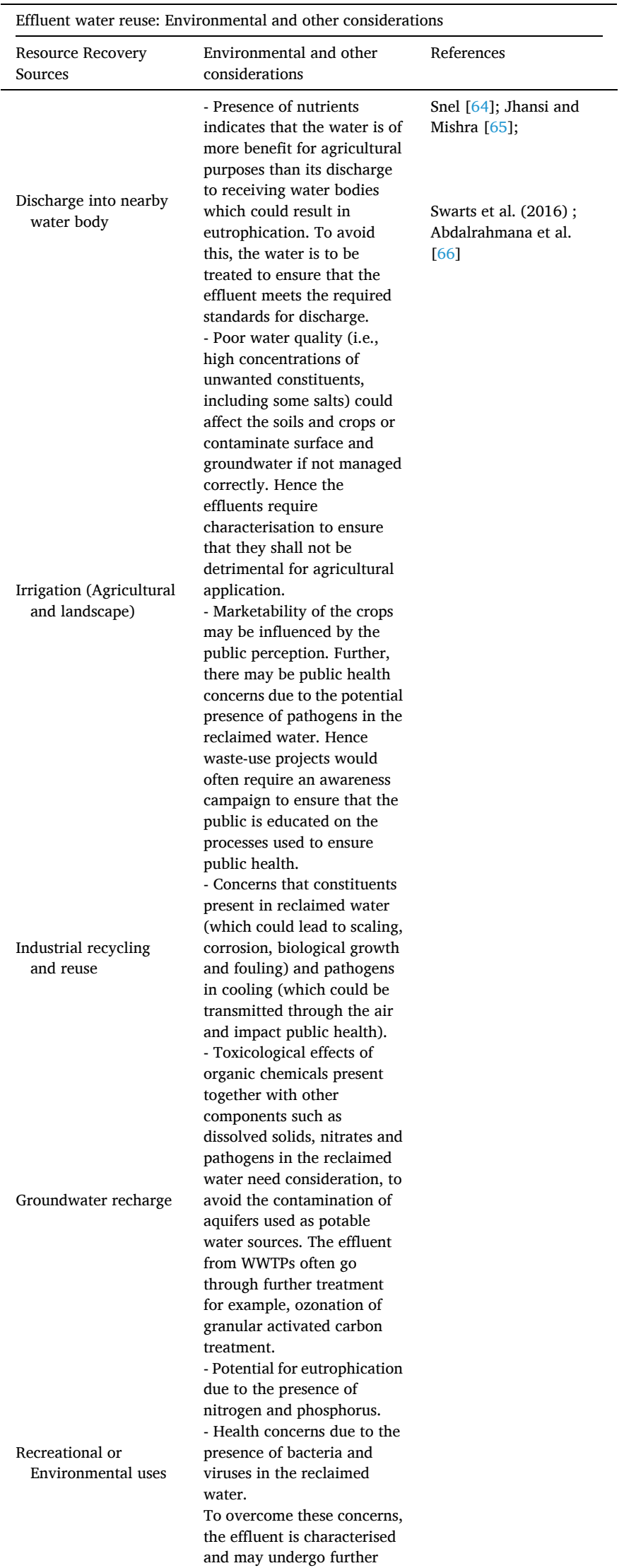

Table 3 (continued)

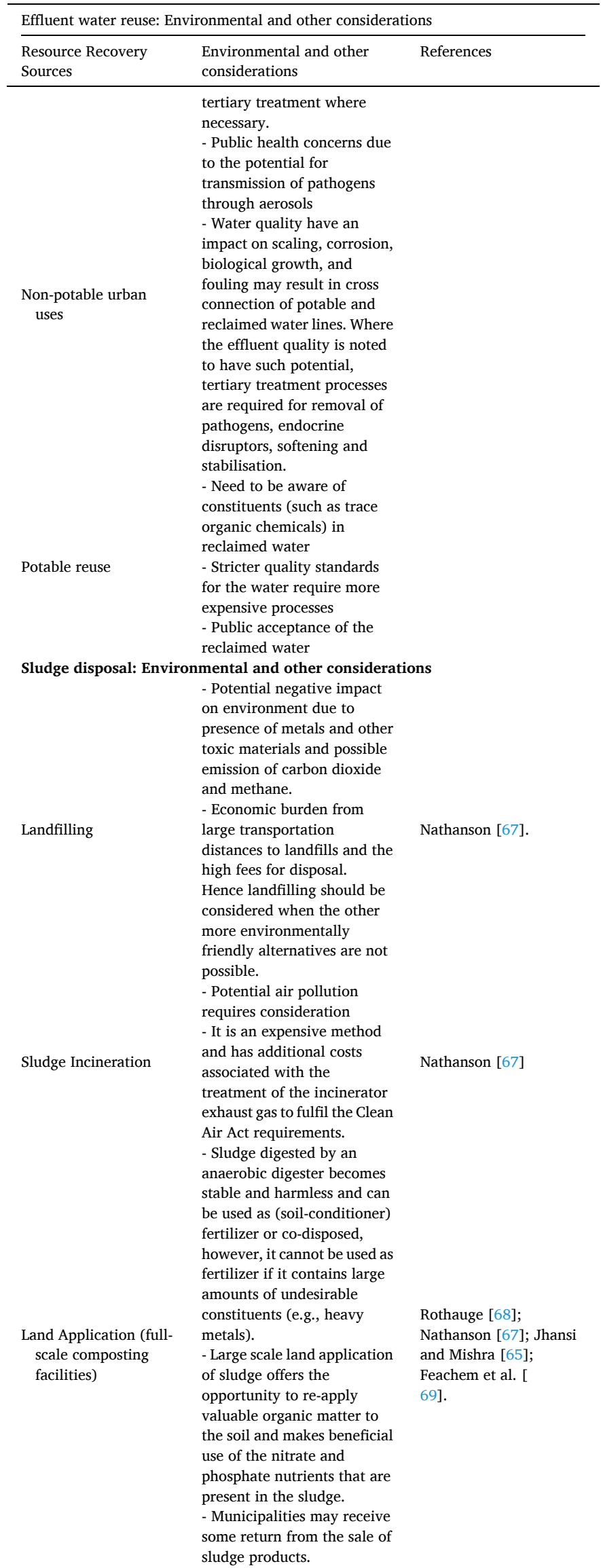


Table 3 (continued)

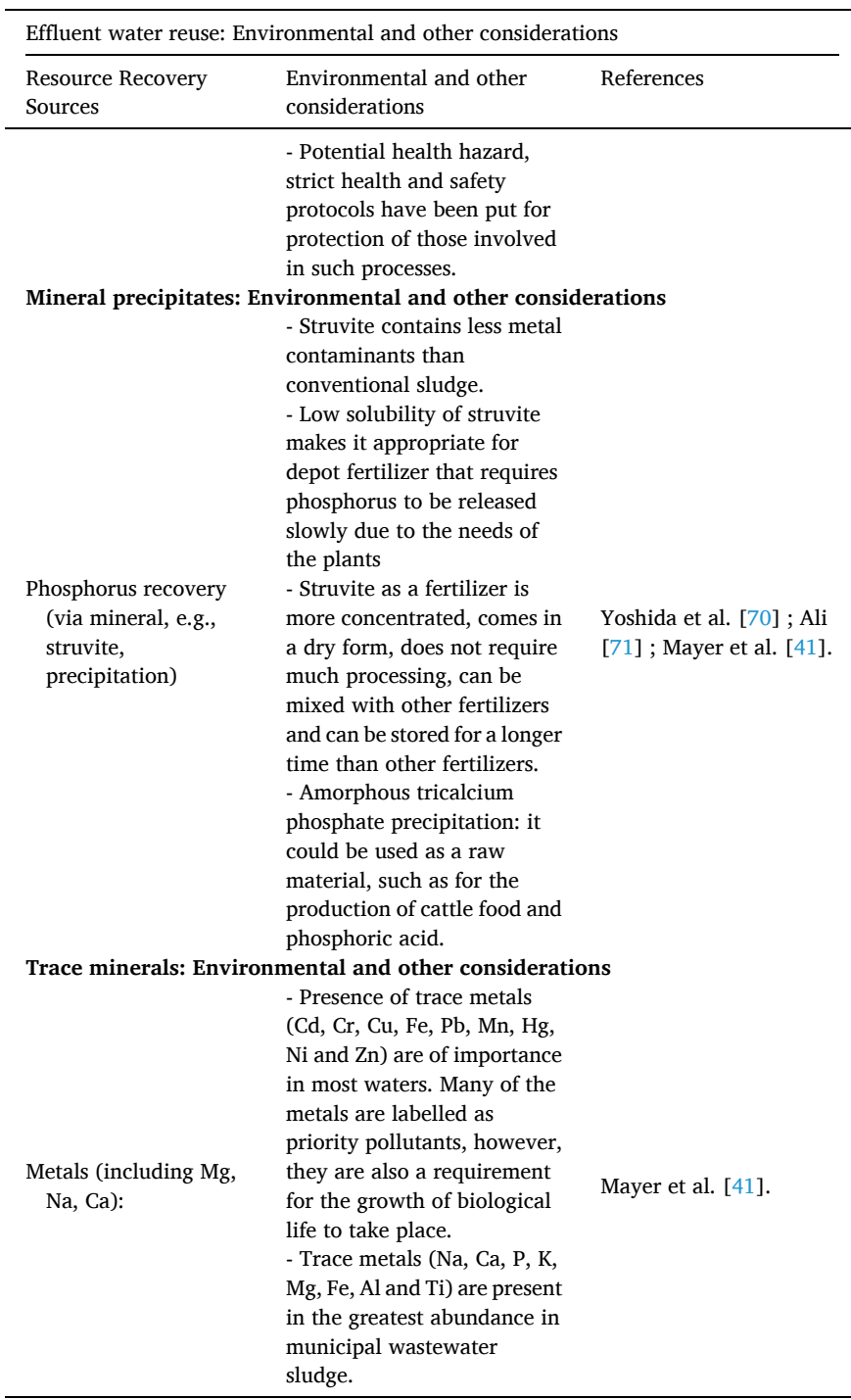

Table 4

A summary of possible applications of biogas in different areas obtained from WRRFs.

\begin{tabular}{lll}
\hline Product & Applications & References \\
\hline Gaseous & Heating buildings, Injection into natural & {$[72,74,73,75,76$,} \\
biomethane & gas pipeline, Agricultural fertilizer & $77]$. \\
Liquid biofuel & Liquid biofuel cells energy carrier, & {$[23,78,79]$.} \\
& Biomethanol, Power generation & \\
Solid nano & Carbon based sustainable nanomaterials & ([80]; Kampioti \\
carbon & & et al. [81]). \\
\hline
\end{tabular}

modes of transportation such as trucks, busses and cars. There is also an increasing interest in the use of compressed and liquified natural gas as fuel for heavy transport. The upgraded form of biogas is completely substitutable for its fossil fuel equivalent [72]. Several countries inject biomethane into the national transmission network for natural gas. This means that households, industries and vehicle fuel stations have access to this renewable gas, however, the gas in the grid is not homogeneous and has both renewable and fossil gas present [73].

Carbon dioxide is classified as a greenhouse gas and therefore its emission into the atmosphere is undesirable. In the South African context, there are limited documented cases of energy generation from waste [23] and the carbon dioxide generated is mostly being released into the atmosphere. Globally, the carbon dioxide emissions from WWTPs are mostly atmospheric and account for most of the carbon footprint of WWTPs. The more profitable option would be to decrease electricity costs by using the biogas produced to generate electricity and/ or heat. Without reuse, the carbon dioxide is simply released into the atmosphere, an especially undesirable destination considering it is a greenhouse gas.

Although current models suggest that there is greater potential for energy recovery from methane than from hydrogen, technology such as fuel cells might make energy recovery from hydrogen more appealing [23]. It must be noted that the addition of hydrogen to a biogas plant would result in the biogas being transformed to almost $100 \%$ methane due to the reaction of the hydrogen with the carbon dioxide [72]. Nitrogen gas is released into the atmosphere; however, it is a valuable nutrient in agriculture and can be converted to fertilizer by the Haber-Bosch process, an energy intensive process [47]. With the increase of energy costs, greenhouse gas regulations, and strictness of effluent requirements, the interest in nitrogen recovery will increase [41].

\section{Modelling approaches to resource recovery}

Resource recovery is a rapidly emerging research area, which promotes the development of several technologies that have the potential to extract different type of organics (e.g., those from food waste, agricultural waste, human or animal waste and bi-products of industrial processes - such as the fatty acids generated from coal to fuel processes), nutrients and/or energy from wastewater. Because the functions of future WRRFs stretch beyond simply meeting the effluent requirements (i.e., also includes optimization of products, such as water, energy and nutrients), a high level of accuracy in predicting system response is needed. Currently developed predictive WRRF mathematical models can play a crucial role in this paradigm shift, acting as tools to assist players in the sector in management of treatment systems, with a focus on reuse and recovery (Lizzaralde et al., 2018).

Mathematical models, for given unit processes of the wastewater treatment system, function to virtually replicate the unit operation such that they can allow for a better understanding of the system processes and their impact on plant performance, hence providing guidance towards proficient system design and optimised operation $([26,82]$; Ikumi, 2020). The virtual replication of the system processes is formulated using series of stoichiometric expressions (i.e., equations that show interaction between compounds) and kinetic expressions (process rates) that are integrated to mimic the wastewater treatment systems biological interactions, together with the chemical and physical processes (Billing and Dold, 1988). Empirical models are based on correlations between the system adjusted design and operating parameters and observed system responses, to recognize parameters essential for the process (i.e., observation when the mechanisms that drive the system responses are not known or are ignored). In contrast, mechanistic models incorporate conceptualised biological, physical and chemical mechanisms known to drive the system operation and performance [83]. Mechanistic models are generally more reliable than empirical models because of they contain scientifically sound approaches to connecting the input components to the predicted outputs. However, the application of empirical models is favoured for wastewater treatment plants, where the model has been finely calibrated against the specific system under observation. The calibration process is also used in generating some confidence in mechanistic models. This process includes ensuring that the sets of equations used to replicate the real system are mass-balanced and checking that model predictions are capable of matching measured experimental data for significant variables known to govern the system response (a sensitivity analysis is often used, especially for complex models, to determine the important parameters that could be adjusted during calibration).

When well calibrated against given systems, the mathematical 
models could be used to generate critical data that is applicable towards long term strategic planning and management of various design and operational options for WRRFs, using a computers' processing capacity.

However, these predictive models need to evolve from focusing on the waste treatment processes into a more system-wide virtual configuration that integrates the waste treatment systems with their pollutant sources (including various sanitation options) and considering the fate of products that are generated during treatment processes. These system-wide tools would not only need to be scientifically sound but should also incorporate decision making/strategy evaluation procedures that prioritise human and environmental health and consider socioeconomic factors. Further, in the development of such tools the preference is to employ simpler models that could provide answers to complex problems rather than complex models to generate answers to problems that can be easily resolved [84]. Several plant-wide steady-state models such as the mass balance spreadsheet developed by Sötemann et al. [85] and Ekama [38] have been developed and are useful in the development of design and operation WWTP tools such as the approach of Wu [86] and Nsengiyumva et al. [84]. Similar progress has been made with more complex plant-wide dynamic simulation models that are capable of simulating WRRF systems (Barat et al., 2013; [87] and [88]).

To ensure that these models are presented and evaluated in a more systematic and rigorous way further research has also been done by Lizarralde et al. [89] in the systematic integration of biochemical, chemical and physico-chemical models and the Benchmark Simulation Modelling (BSM) task group $[90,91]$ that present a testing platform for plant-wide performance evaluation of operational/control strategies Numerous studies have been presented on the use of mathematical models to simulate strategies around design and operation of wastewater treatment systems, such as introduction of new technologies/ processes or improvements in the system configuration. Table 5 provides some recent examples, where models have been used to virtually replicate such strategies.

The past decade has seen an increase in the use of models by wastewater treatment process utility staff (plant supervisors, engineers and operators) [96]. However, along with such development, there is a need for a new generation of (plant-wide) engineering tools to simulate resource recovery options before/after implementation [97]. Hence, there have been various increasingly sophisticated applications to allow for the transition of these tools towards WRRF modelling. These include simulating different strategies to nutrient ( $\mathrm{N}$ and $\mathrm{P}$ ) recovery, energy generation, greenhouse gas mitigation, biomass specialization for new conversion pathways. In many of these topics, there was an overarching challenge on how best to bridge the gap between the current modelling research findings and practical implementation (e.g., development of utilisable tools). This has given rise to various debates about the best way to improve model's accuracy, where it is lacking in full scale systems. Hence improvements to various existing bioprocess models have been done to ensure practicality in use for process control and system operation. Examples of such improvements include (i) integration of biological and physicochemical models to allow for virtual replication of nutrient recovery processes (i.e., including biological uptake, release and mineral precipitation (Ikumi and Ekama, 2019), (ii) integration of computational fluid dynamics (CFD) and biokinetic models to include the role of hydrodynamics in WRRF unit operations [98], (iii) improved gas-liquid mass transfer processes that can replicate oxygen transfer, energy use and greenhouse gas emissions, (iv) attempts to virtually replicate new resource recovery technologies such as AGS,THP [27], struvite PPT, partial nitrification/anammox [95] etc. and their inclusion to integrated system-wide models. Integration of established technologies in novel process schemes (Wan et al., 2016; [99]).

The practical application of these numerical models, by various researchers have demonstrated usefulness in optimising design and operation of WRRFs, with consideration to environmental and economic criteria. However, because the models employed are not generic and require adaptation to suit the scope and objectives of their application
Table 5

Examples of simulated strategies and applications of WRRFs.

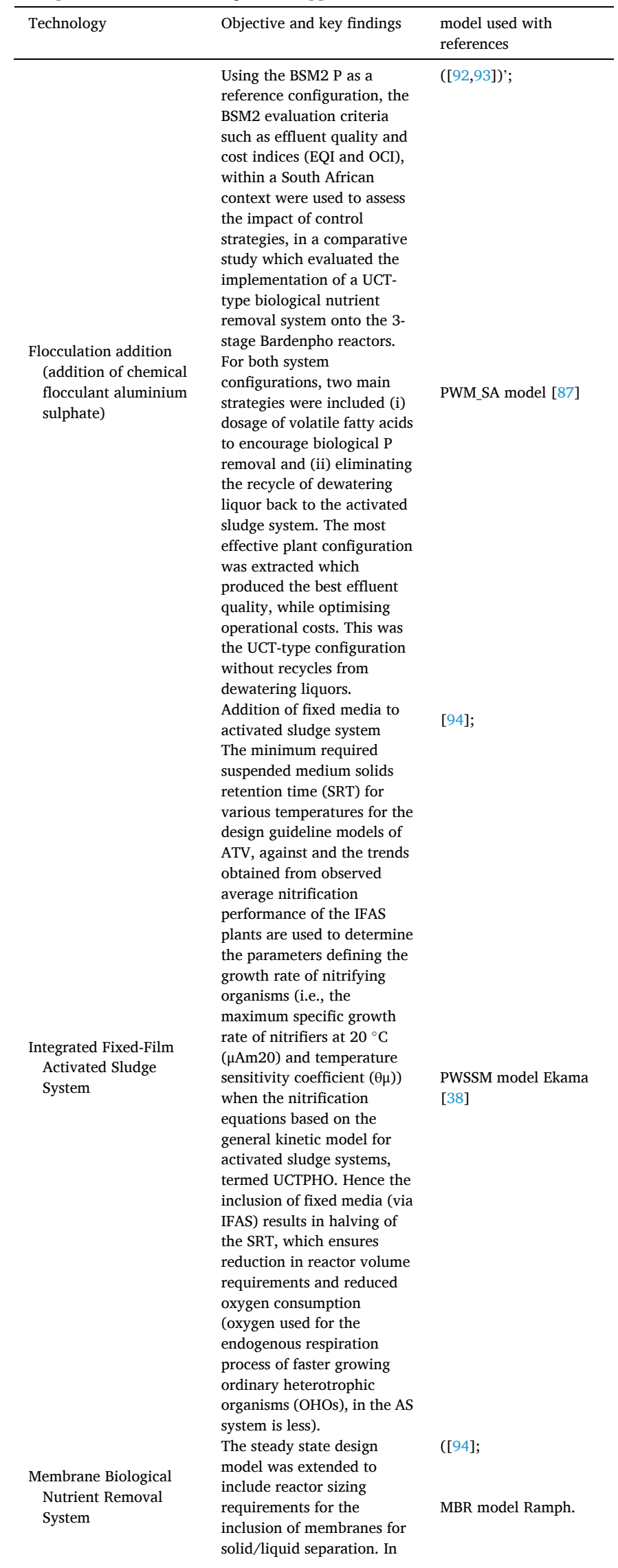

(continued on next page) 
Table 5 (continued)

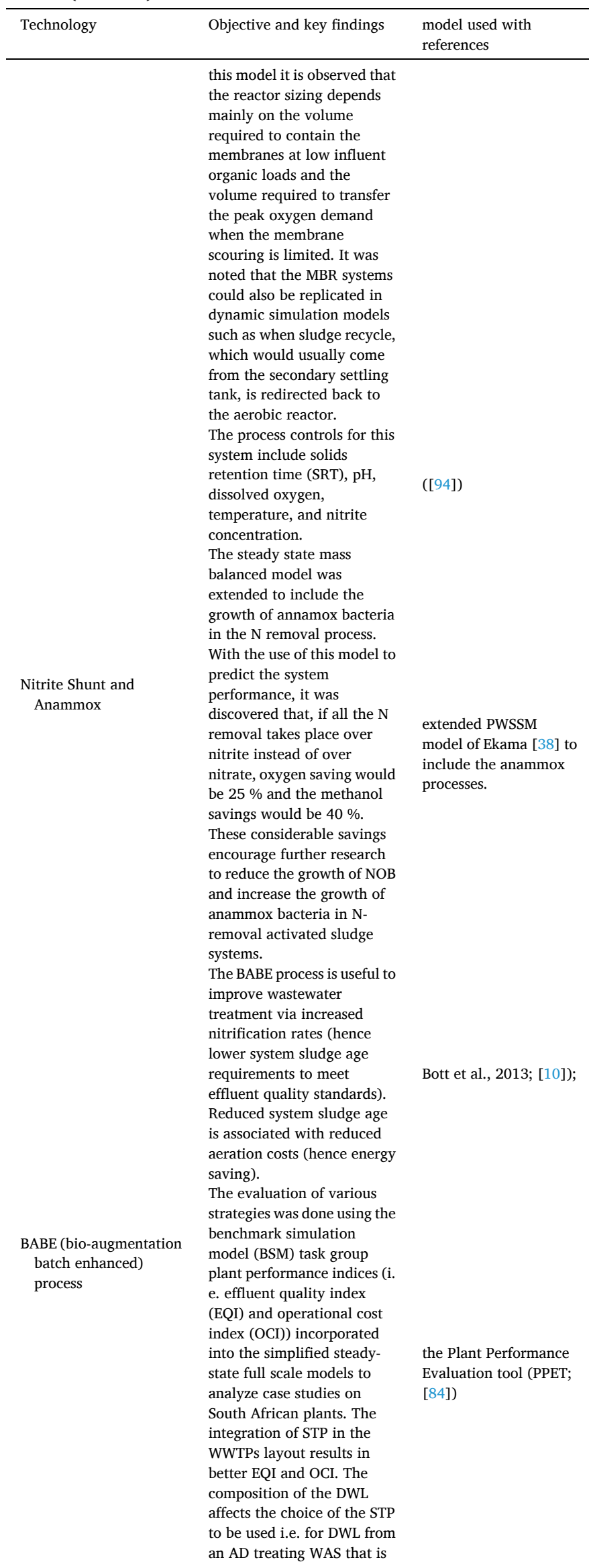

Table 5 (continued)

\begin{tabular}{lll}
\hline Technology & Objective and key findings & $\begin{array}{l}\text { model used with } \\
\text { references }\end{array}$ \\
\hline & not P rich the recommended \\
side-stream treatment & operation would be the \\
& BABE process rather than the \\
& struvite precipitation. \\
& A modified version of the \\
& Benchmark Simulation \\
& Model No. 2 (BSM2) was \\
& used as test platform was \\
& used to test the effects that \\
& control/operational \\
struvite crystallization & precipitation may have on \\
plant-wide phosphorus (P) & transformations in \\
& wastewater treatment plants \\
& (WWTP). Model-based \\
analysis shows that the \\
combination of an \\
ammonium and total \\
suspended solids control \\
strategies better adapts the \\
system to influent dynamics, \\
improves biological P \\
removal potential (41 \%), \\
increases nitrification \\
/denitrification efficiency \\
(18\%) and reduces aeration \\
energy (21 \%). \\
\hline
\end{tabular}

[100] further developments are necessary to allow for their uptake by end-users. Such developments included the preparation of data reconciliation and parameter estimation protocols (in cases where data is available) and statistical tools that could act as input generators, for instance where data availability is limited. For example, the probabilistic fractionator of Brouckaert et al. [101] that combines available plant data with assumptions based on literature or local experience to estimate the wastewater composition. This minimizes the requirement for extensive additional measurements that would normally be required to characterize the wastewater for modelling purposes. Further possibilities include, conceptual frameworks for an online supervision and control of decision support system, which involve the incorporation of multiple sensor technology and artificial intelligent systems to work with the predictive capacity of simulation models. The sensors that measure different parameters at the influent to the treatment systems and in the reactors can be generate data to mathematical models, tailored to suit the configuration of the existing WRRF system and the consolidated sensor measurements are used by the model to calculate important variables that then need not be measured, in real time. This allows for the models to calculate predicted system responses to measured changes, hence provide early warnings that, where necessary would prompt control adjustments for the mitigation of risk.

\section{Challenges of wastewater resource recovery in rural South Africa}

South Africa, being a water-stressed country, has suffered a general threat to river health and over-exploitation of the national water system for years. Moreover, the lack of adequate sanitation infrastructure in the country's rural communities has been steadily rising. This has resulted in rivers becoming increasingly contaminated with human waste and untreated effluent (i.e., raw sewage) being discharged into rivers [102]. Although sewerage networks and waste treatment plants are not very visible forms of infrastructure (with the sewage reticulation networks buried under roads and plants mostly located at the outskirts of regions) there is a major requirement for South African municipalities to address the backlog in service provision for the water and sanitation sector. 
Hence, with limited investment in new technologies and declining maintenance of existing ones, most rural municipalities do not have the required infrastructure to support resource recovery facilities (Bild, 2016). Beyond poor infrastructure and mismanagement of resources, a major contributor to the water and sanitation problems in rural South Africa is the shortfall in human resource potential, for the various stake-holder levels up to and including the decision makers. Moreover, because various resource recovery activities rely heavily on operator skills (e.g., thermal combustion and bio-gasification), successful implementation and regulation of resource recovery systems in rural South Africa would require awareness and proper training of the public and stakeholders to ensure growth of suitable expertise and practices (Florin-Constantin and Mohammad, 2017).

A major challenge in implementing resource recovery systems in the systems of water supply and sanitation that are most efficiently linked to resource recovery is the fact that they are not widely accepted by the public. The most common perception is that a sanitation system that is geared to maximum comfort and greatest distancing from the waste (i.e., fully flushed toilets linked to centralised wastewater treatment plants) is the solely acceptable and dignified form of sanitation, with most alternative options being a temporary measure. Hence there is further need for proper and open communication with the public and stakeholders for awareness on the benefits of alternative systems that allow for resource recovery and to ensure that the alternative systems are improved in quality and comfort [103]. To provide structured incentives for waste reuse and resource recovery is of importance in South Africa, because the current alternative waste treatment and recovery options are limited and seem expensive to implement, relative to less environmentally friendly methods (e.g., use of landfills). With most recovered waste being under-priced, the costs of waste management are not fully appreciated by consumers and industry, and the private sector is slow to respond to the resource recovery opportunities. Further, the governance required to implement structured measures towards an enabling environment for resource recovery activities can be challenging, with the rapidly transforming rural and peri-urban socio-economic contexts. The increasing regulatory requirements in South Africa, over the past decade, to minimise environmental and human health impacts while promoting resource recovery, have resulted in difficulties to ensure compliance and profitable recovery of resources [104]. Additional difficulties in resource recovery programmes have been the overlapping of roles and responsibilities taken by the formal municipal authorities and the more informal traditional regional authorities (e.g., municipalities that are obliged to provide water and sanitation services but not authorised to establish control over the systems). Hence, there is a requirement for efficient means of cooperation between municipalities and traditional authorities to allow for clear division of roles and coordination of governance, planning and implementation in the sector [103].

Efforts to minimise waste and promote resource recovery, revision of current water and sanitation systems will require innovation, not only on the technical aspects, but also in financial, social, cultural, environmental and governance aspects. Potential practices in rural areas would include utilisation of waste (human, agricultural, food, etc) for the preparation of animal fodder, briquetting, anaerobic digestions (to obtain biogas for cooking and other basic needs) and using locally treated water to support agricultural productivity. Such solutions are based on decentralisation but could be integrated into one rural waste to resource recovery complex [105]. Further, the provision of opportunities for these activities should be promoted through the development of adequate policies and regulations, useful partnerships between authorities and stakeholders, tax incentives and new financing mechanisms for capital investment in the required infrastructure and its maintenance.

\subsection{Supportive prospects for water and resource recovery facilities}

Overall, the outlook is positive for wastewater-based resource recovery systems in rural South Africa. The ease of access to water quality monitoring, through modelling tools and the involvement of various stake holders, provides the necessary nourishment for successful implementation of full-scale projects. The challenge is to begin perceiving wastewater as a resource that requires management at various levels and to include the fate of the products generated from wastewater treatment systems as part of the decision-making processes for design and operation of WRRFs. Policies that could support such initiatives include those that:

(i) Allow for re-introduction of recovered products from waste streams as end products that are safe to use (i.e., redefining waste as resource), through the standardization of these products and providing some legal certainty in the recyclable materials markets.

(ii) Assurance of Environmental protection and human safety through policies that establish effective links between water, sanitation and resource recovery with the frameworks of national public health and environmental protection. Hence resource recovery should not be at the expense of human or environmental health.

(iii) Support the provision of free basic services for all of its citizens. This includes minimum access to water and sanitation services. The services should be covered within the entire city and should include all technical components required to be fully functional.

(iv) Limit discharge of waste sludge to landfills (by specifying allowing only non- hazardous types wastes to be discharged at a given cost), incentivise reduction in wastewater discharge to receiving water bodies and encourage sludge and water reuse (e. g., in agriculture)

(v) Encourage inclusive participation of all stakeholders (e.g., heads of local municipalities, system operators, producers, users, etc.), providing clear roles and mandates with allocation of required authority to fulfil given responsibilities, including cooperative mechanisms and best practices, where appropriate.

Following this review future prospects in of this research, towards informed decision making for better design and operation of WRRFs include (i) Advancement of accurate, cost saving and efficient data generation collection techniques, (ii) promote the establishment of centralised virtual networks that would allow for water and wastewater analysis needs to be met, (iii) development of performance indices that evaluate entire water and sanitation systems including the fate of WRRF products, (iv) converting system-wide models to realistic tools that could be used in transforming WWTPs to WRRFs and (v) connecting enhanced data procurement methods to mathematical models that virtually replicate water and sanitation systems of given catchment areas in order to apply modelling tools for evaluation of system-wide strategies.

\section{Conclusions}

This review aims for the long-term impact of promoting the conversion of wastewater treatment systems in South Africa into low cost and environmentally sustainable water and resource recovery facilities of the future, especially in the rural areas.. Possible ways of resource recovery such as effluent water reuse, sludge disposal, mineral precipitates (such as struvite) and nitrogen recovery have been explored.. The market potentials of recovered water, energy, fertilizer and other products are specific to a given region and depend on the volumes demanded, the quantities contained in wastewater streams and the recovery yields obtainable. Mathematical tools that track material components through wastewater treatment systems, could be useful to 
include the fate their generated products in decision-making processes to allow for conversion of WWTPs to WRRFs.

\section{Declaration of Competing Interest}

The authors declare that they have no known competing financial interests or personal relationships that could have appeared to influence the work reported in this paper.

\section{Acknowledgments}

The authors acknowledge funding from VLIR-UOS,Flemish Interuniversity Council for Development Cooperationin the framework of South Initiatives (WaRe-SimPLE project nr ${ }^{\circ}$ SI2020SEL094 01/01/2020 - 31/12/2021) as cooperation between KU Leuven Belgium and University of Limpopo South Africa. Both Emilia Motoasca and Abhishek Dutta were with KU Leuven and involved in the preparation and revision of the grant proposal.

\section{References}

[1] SAICE, Infrastructure Report Card for South Africa, accessed at, 2017, http://sa ice.org.za/wp-content/uploads/2017/09/SAICE-IRC-2017.pdf.

[2] M. Toxopeüs, The State of Sanitation and Waste Water Treatment Services in SA, Politics Web [https://www.politicsweb.co.za/opinion/the-state-of-sanitationand-waste-water-treatment-accessed 1 May 2020], 2019.

[3] J.W.H. Friedo, Talking dirty - effluent and sewage irreverence in South Africa: a conservation crime perspective, Cogent Soc. Sci. 5 (1) (2019), 1701359.

[4] W. Mo, Q. Zhang, Energy-nutrients-water nexus: integrated resource recovery in municipal wastewater treatment plants, J. Environ. Manage. 127 (2013) 255-267.

[5] UNICEF website: https://www.unicef.org/infobycountry/media_86521.html [accessed on 1 May 2020].

[6] V. Masindi, L. Duncker, State of Water and Sanitation in South Africa, Water Research Commission Report, 2016, 2016.

[7] United Nations Conference on Sustainable Development, Rio+20 https:// sustainabledevelopment.un.org/rio20 [accessed on 1 May 2020].

[8] S.A. Mitchell, M.P. de Wit, J.N. Blignaut, D. Crookes, Wastewater Treatment Plants: the Financing Mechanisms Associated With Achieving Green Drop Rating, Water Research Commission Report, 2014.

[9] DWS Green Drop Report, Executive Summary, accessed at, 2013, http://www.dw a.gov.za/Documents/Executive\%20Summary\%20for\%20the\%202013\%20Green \%20Drop\%20Report.pdf.

[10] D. Ikumi, A. Matimba, D. Modiri, Y. Coothen, O. Nsengiyumva, K. Naidoo, J. Doutor, M. Kerstholt, S. Oyebode, M. Vogts, T. Pandither, F. Renaux J. Broodryk, S. Power, The Impact of Sludge Return Liquors in South African Wastewater Treatment Plants. WRC Report No. TT 800/19, Water Research Commission, Pretoria, 2019.

[11] Environmental Performance Index, Environmental Performance Index, 2020. https://epi.envirocenter.yale.edu/.

[12] Joshua N. Edokpayi, John O. Odiyo, Olatunde S. Durowoju, Impact of Wastewater on Surface Water Quality in Developing Countries: A Case Study of South Africa, IntechOpen Book Chapter, Water Quality., 2017.

[13] I. Nhapi, H.J. Gijzen, A 3-step strategic approach to sustainable wastewater management, Water SA 31 (1) (2005) 133-140.

[14] J. Dhote, S. Ingole, A. Chavhan, Review on waste water treatment technologies, Int. J. Eng. Res. Technol. 1 (2012) 1-10.

[15] N. Khouri, J.M. Kalbermatten, C. Bartone, The Reuse of Wastewater in Agriculture: a Guide for Planners. UNDP - World Bank Water and Sanitation Program, The World Bank, Washington, DC, 1994.

[16] A. Dutta, C. Davies, D.S. Ikumi, Performance of upflow anaerobic sludge blanket (UASB) reactor and other anaerobic reactor configurations for wastewater treatment: a comparative review and critical updates, J. Water Supply: Res. Technol. - AQUA 67 (8) (2018) 858-884.

[17] R. Scheepers, M. van de Merwe-Botha, Energy optimization considerations for wastewater treatment plants in South Africa - a realistic perspective, ReSource 15 (4) (2013) 40-44.

[18] E. Musvoto, D. Ikumi, Energy Use Reduction in Biological Nutrient Removal Wastewater Treatment Plant - a South African Case Study. WRC Report No. TT 654/15, Water Research Commission, Pretoria, 2016.

[19] X. Tao, W. Chengwen, in: Energy Consumption in Wastewater Treatment Plants in China. Procs: IWA World Congress on Water, Climate Energy, Copenhagen, Denmark, 2012, October 29-31, 2012.

[20] Y. Sun, M. Lu, Y. Sun, Z. Chen, H. Duan, D. Liu, Application and evaluation of energy conservation technologies in wastewater treatment plants, Appl. Sci. (Basel) 9 (2019) 4501.

[21] K. Niu, J. Wu, L. Qi, Q. Niu, Energy intensity of wastewater treatment plants and influencing factors in China, Sci. Total Environ. 670 (2019) 961-970.

[22] S. Longo, B.M. D'antoni, M. Bongards, A. Chaparro, A. Cronrath, F. Fatone, J. M. Lema, M. Mauricio-Iglesias, A. Soares, A. Hospido, Monitoring and diagnosi of energy consumption in wastewater treatment plants. A state of the art and proposals for improvement, Appl. Energy 179 (2016) 1251-1268.

[23] S. Burton, B. Cohen, S. Harrison, S. Pather-Elias, W. Stafford, R. van Hille, H. von Blottnitz, Energy From Wastewater - a Feasibility Study. WRC Report No. TT 399/09, Water Research Commission, Pretoria, 2009.

[24] W. Stafford, B. Cohen, S. Pather-Elias, H. Von Blottnitz, R. Van Hille, S. T. Harrison, S.G. Burton, Technologies for recovery of energy from wastewaters: applicability and potential in South Africa, J. Energy South. Afr. 24 (2013), 0000 .

[25] C.D. Swartz, M. van der Merwe-Botha, S.D. Freese, Energy Efficiency in the South African Water Industry: a Compendium of Best Practices. WRC Report No. TT 565/13, Water Research Commission, Pretoria, South Africa, 2013.

[26] G. Ekama, Optimizing water and resource recovery facilities (WRRF) for energy generation without compromising effluent quality, in: Procs: IWA NRR-LWWTP 2017 Conference, 7-10 November, Chongqing, China, 2017.

[27] P. Aichinger, C. DeBarbadillo, A. Al-Omari, B. Wett, Hot topic' - combined energy- and process modelling in thermal hydrolysis-systems, Water Sci. Technol. 79 (1) (2019) 84-92.

[28] Y. Gu, Y. Li, X. Li, P. Luo, H. Wang, X. Wang, J. Wu, F. Li, Energy self-sufficient wastewater treatment plants: feasibilities and challenges, Energy Proc. 105 (2017) 3741-3751.

[29] E. Musvoto, N. Mgwenya, H. Mangashena, A. Mackintosh, Energy Recovery From Wastewater Sludge - a Review of Appropriate Emerging and Established Technologies for the South African Industry. WRC Report No. TT 752/18, Water Research Commission, Pretoria, 2018.

[30] J.N. Zvimba, E.V. Musvoto, Modelling energy efficiency and generation potential in the South African wastewater services sector, Water Sci. Technol. 81 (5) (2020) 876-890.

[31] L.D. Nghiem, K. Koch, D. Bolzonella, J.E. Drewes, Full scale co-digestion of wastewater sludge and food waste: bottlenecks and possibilities, Renewable Sustainable Energy Rev. 72 (2017) 354-362.

[32] Z. Zahan, M.Z. Othman, W. Rajendram, Anaerobic codigestion of municipal wastewater treatment plant sludge with food waste: a case study, Biomed Res. Int. (2016). Article ID 8462928.

[33] N. Mills, P. Pearce, J. Farrow, R.B. Thorpe, N.F. Kirkby, Environmental \& economic life cycle assessment of current \& future sewage sludge to energy technologies, Waste Manag. 24 (1) (2014) 185-195.

[34] R. Sinnott, G. Towler, Costing and Project Evaluation, Chemical Engineering Design: SI Edition, fifth ed., Butterworth-Heinemann, Oxford, 2009, p. 247.

[35] Mills, Life cycle assessment of advanced digestion process configurations for sewage sludge - a UK perspective. 4th Symposium of Energy From Waste (Venice: Elsevier, Journal of Waste Management), 2012.

[36] K. Svardal, H. Kroiss, Energy requirement for wastewater treatment, Water Sci. Technol. 64 (2011). EM10347.

[37] G.A. Ekama, J.A. Wilsenach, G.H. Chen, Saline sewage treatment and source separation of urine for more sustainable urban water management, Water Sci. Technol. 64 (6) (2011) 1307-1316.

[38] G.A. Ekama, Using bioprocess stoichiometry to build a plant-wide mass balance based steady-state WWTP model, Water Res. 43 (8) (2009) 2101-2120.

[39] A.A. Ilemobade, J.R. Adewumi, J.E. Van Zyl, Assessment of the Feasibility of Using a Dual Water Reticulation System in South Africa. WRC Report 1701, Water Research Commission, Pretoria, 2008.

[40] Department of Environmental Affairs, South Africa State of Waste Report - First Draft Report, Department of Environmental Affairs, Pretoria, 2018.

[41] B.K. Mayer, L.A. Baker, T.H. Boyer, P. Drechsel, M. Gifford, M.A. Hanjra, P. Parameswaran, J. Stoltzfus, P. Westerhoff, B.E. Rittmann, Total value of phosphorus recovery, Environ. Sci. Technol. 50 (13) (2016) 6606-6620.

[42] P. Drechsel, G. Danso, M. Qadir, Wastewater use in agriculture: challenges in assessing costs and benefits, in: P. Drechsel, M. Qadir, D. Wichelns (Eds.), Wastewater: Economic Asset in an Urbanizing World., Springer, Dordrecht, Netherlands, 2015, pp. 139-152.

[43] UN-Water, Wastewater Management A UN-Water Analytical Brief (Analytical Brief), UN Water, 2015.

[44] K. Than, Reclaimed Wastewater for Drinking: Safe but Still a Tough Sell., Natl. Geogr. News, 2012. URL https://www.nationalgeographic.com/news/2012/1/ 120131-reclaimed-wastewater-for-drinking/ (accessed 04.26.20).

[45] B. Jiménez Cisneros, Water recycling and reuse: an overview.. Water Reclamation and Sustainability, 2014, pp. 431-454. ISBN: 9780124165762.

[46] S. Daneshgar, A. Callegari, A.G. Capodaglio, D. Vaccari, The potential phosphorus crisis: resource conservation and possible escape technologies: a review, Resources 7 (2) (2018) 37.

[47] J.P. Van der Hoek, R. Duijff, O. Reinstra, Nitrogen recovery from wastewater: possibilities, competition with other resources, and adaptation pathways, Sustainability 10 (12) (2018) 4605, https://doi.org/10.3390/su10124605.

[48] P.A. Vanrolleghem, C. Vaneeckhaute, Resource recovery from wastewater and sludge: modelling and control challenges, in: Global Challenges: Sustainable Wastewater Treatment and Resource Recovery. Procs: IWA Specialist Conference: Global Challenges - Sustainable Wastewater Treatment and Resource Recovery, 26-30 October, Kathmandu, Nepal, 2014.

[49] M. Ahmed, H. Chowdhury, H. Rahman, A. Hossain, S. Uddin, Prospects of using wastewater as a resource-nutrient recovery and energy generation, Rev. Paper: Am. J. Environ. Sci. 11 (2) (2015) 99-114.

[50] C.M. Meht, W.O. Khunjar, V. Nguyen, S. Tait, D.J. Batstone, Technologies to recover nutrients from waste streams: a critical review, Crit. Rev. Environ. Sci. Technol. 45 (4) (2015) 385-427. 
[51] B. Verster, Exploring the Factors at Play to Make Wastewater Biorefineries a Reality, PhD Thesis, University of Cape Town, Cape Town, South Africa, 2019.

[52] WHO, Drinking-water [WWW Document]. World Health Organ, URL https:// www.who.int/news-room/fact-sheets/detail/drinking-water (accessed 04.25.20), 2019.

[53] M. Otoo, P. Drechsel, Resource Recovery From Waste: Business Models for Energy, Nutrient and Water Reuse in Low- and Middle-income Countries, Routledge, New York, 2018, pp. 4-7. Chapter1.

[54] Integrated Resources Recovery Centre Brief, Integrated Resources Recovery Centre Brief, accessed at:, 2016 http://ahkmt.org/wp-content/uploads/201 6/09/IRRC-BRIEF.pdf.

[55] Resource recovery and energy production, Resource Recovery and Energy Production, 2017. Website: https://www.phila.gov/water/sustainability/energy/ Pages/default.aspx [accessed on 13 May 2020].

[56] K. Solon, E.I.P. Volcke, M. Spérandio, M.C.M. van Loosdrecht, Resource recovery and wastewater treatment modelling, Environ. Sci. Water Res. Technol 5 (2019) 631-642.

[57] S.R. Qasim, Wastewater Treatment Plants Planning, Design, and Operation, second edition, CRC Press LLC, America, 2000.

[58] C. Prouty, S. Mohebbi, Q. Zhang, Socio-technical strategies and behaviour change to increase the adoption and sustainability of wastewater resource recovery systems, Water Res. 137 (2018) 107-119.

[59] F. Bichai, A. Cabrera Flamini, The water-sensitive city: implications of an urban water management paradigm and its globalization, WIREs Water 5 (3) (2018).

[60] National Association of Clean Water Agencies (NACWA), Water Resources Utility of the Future. A Call for Federal Action, NACWA., Washington DC, 2013.

[61] J.J. Qin, M.N. Wai, M.H. Oo, K.A. Kekre, H. Seah, Feasibility study for reclamation of a secondary treated sewage effluent mainly from industrial sources using a dual membrane process, Sep. Purif. Technol. 50 (3) (2006) 380-387.

[62] T. Asano, F.L. Burton, H.L. Leverenz, R. Tsuchihashi, G. Tchobanoglous, Water Reuse: Issues, Technologies and Applications, McGraw-Hill Professional., New York, 2007.

[63] F. Brissaud, Technologies for water regeneration and integrated management of water resources', in: S. Sabater, D. Barceló (Eds.), Water Scarcity in the Mediterranean: Perspectives Under Global Change, Springer, Heidelberg, Germany, 2010.

[64] M. Snel, Re-use of wastewater- its advantages and disadvantages specifically from an institutional and socio-cultural perspective. Re-Use of Wastewater: Advantages and Disadvantages. Presented at the Use of Appropriate Treated Domestic Wastewater in Irrigated Agriculture, WIO, Wageningen, The Netherlands, 2002

[65] S.C. Jhansi, S.K. Mishra, Wastewater treatment and reuse: sustainability options, Cons. J. Sustain. Dev. 10 (2013) 1-15.

[66] G.A.M. Abdalrahmana, H.L. Sai, I. Snounu, P. Kumar, A. Sefelnasr, M. Sherif, A. El-Shafie, Review on wastewater treatment ponds clogging under artificial recharge: impacting factors and future modelling, JWPE (2020), https://doi.org/ 10.1016/j.jwpe.2020.101848.

[67] J.A. Nathanson, Sludge management, in: J.A. Nathanson (Ed.), Basic Environmental Technology - Water Supply, Water Management, and Pollution Control., Prentice Hall, Ohio, 2003.

[68] B. Rothauge, Biogas to Energy at Municipal Wastewater Treatment Works, GIZ, Pretoria, 2015. URL: http://cityenergy.org.za/uploads/resource_327.pdf (accessed 04.25.20).

[69] R.G. Feachem, D.J. Bradley, H. Garelick, D.D. Mara, Appropriate Technology for Water Supply and Sanitation, The World Bank, Washington D.C, 1981.

[70] H. Yoshida, T.H. Christensen, C. Scheutz, Life cycle assessment of sewage sludge management: a review, Waste Manag. Res. 31 (11) (2013) 1083-1101.

[71] I. Ali, Struvite Crystallization From Nutrient Rich Wastewater, PhD Thesis, James Cook University, Queensland, Australia, 2005.

[72] A. Fagerström, T. Al Seadi, S. Rasi, T. Briseid, The role of anaerobic digestion and biogas in the circular economy, in: J.D. Murphy (Ed.), IEA Bioenergy Task 37, Ireland., 2018.

[73] W. Urban, Biomethane injection into natural gas networks, in: A. Wellinger, J. Murphy, D. Baxter (Eds.), Biogas Handbook., Woodhead Publishing, 2013, pp. 378-403, https://doi.org/10.1533/9780857097415.3.378.

[74] A.T. Penteado, M. Kim, H.R. Godini, E. Esche, J.U. Repke, Biogas as a renewable feedstock for green ethylene production via oxidative coupling of methane: preliminary feasibility study, Chem. Eng. Trans. 61 (2017) 589-594.

[75] B. Demirel, P. Scherer, Trace element requirements of agricultural biogas digesters during biological conversion of renewable biomass to methane, Biomass Bioenergy 35 (3) (2011) 992-998.

[76] T.G. Poulsen, L. Adelard, Improving biogas quality and methane yield via codigestion of agricultural and urban biomass wastes, Waste Manag. 54 (2016) $118-125$.

[77] J. Hoarau, Y. Caro, I. Grondin, T. Petit, Sugarcane vinasse processing: toward a status shift from waste to valuable resource. A review, JWPE 24 (2018) 11-25, https://doi.org/10.1016/j.jwpe.2018.05.003.

[78] H. Hahn, B. Krautkremer, K. Hartmann, M. Wachendorf, Review of concepts for a demand-driven biogas supply for flexible power generation, Renewable Sustainable Energy Rev. 29 (2014) 383-393.

[79] C. Herbes, Marketing of biomethane, in: C. Herbes, C. Friege (Eds.), Marketing Renewable Energy. Management for Professionals., Springer, 2017.

[80] F. Ferdinand Hof, K. Kampioti, K. Huang, C. Jaillet, A. Derré, P. Poulin, H. Yusof, T. White, K. Koziol, C. Paukner, A. Pénicaud, Conductive inks of graphitic nanoparticles from a sustainable carbon feedstock, Carbon 111 (2017) 142-149.
[81] K. Kampioti, C.F. Matos, F. Galembeck, C. Jaillet, A. Derre, A.J.G. Zarbin, A. Pénicaud, Highly conducting, sustainable, nanographitic rubber composites, ACS Omega 3 (2018) 1367-1373.

[82] C. Kazadi Mbamba, X. Flores-Alsina, D. John Batstone, S. Tait, Validation of a plant-wide phosphorus modelling approach with minerals precipitation in a fullscale WWTP, Water Res. 100 (2016) 169-183.

[83] P.A.L.N.S. Sam-Soon, M.C. Wentzel, P.L. Dold, R.E. Loewenthal, Gv.R. Marais, Mathematical modelling of upflow anaerobic sludge bed (UASB) systems treating carbohydrate waste waters, Water SA 17 (2) (1991) 91-106.

[84] O. Nsengiyumva, Y. Coothen, K. Naidoo, D. Ikumi, Water Sa (2020) (Accepted).

[85] S. Sötemann, N. Ristow, M. Wentzel, G. Ekama, A steady-state model for anaerobic digestion of sewage sludges, Water SA 31 (4) (2005).

[86] W.Y.X. Wu, Development of a Plant-Wide Steady-state Wastewater Treatment Plant Design and Analysis Program., MSc. Thesis, University of Cape Town, Cape Town, South Africa, 2015.

[87] D.S. Ikumi, T.H. Harding, M. Vogts, M.T. Lakay, H.Z. Mafungwa, C.J. Brouckaert, G.A. Ekama, Mass Balances Modelling Over Wastewater Treatment Plants III. WRC Report No. 1822/1/14, Water Research Commission, Pretoria, 2015.

[88] X. Flores-Alsina, K. Solon, C. Kazadi Mbamba, S. Tait, U. Jeppsson, K.V. Gernaey, D.J. Batstone, Modelling phosphorus, sulphur and iron interactions during the dynamic simulation of anaerobic digestion processes, Water Res. 95 (2016) 370-382.

[89] I. Lizarralde, T. Fernández-Arévaloa, C.J. Brouckaert, Vanrolleghem Pa, D. S. Ikumi, G.A. Ekama, E. Ayesa, P. Grau, A new general methodology for incorporating physicochemical transformations into multi-phase wastewater treatment process models, Water Res. 74 (5) (2015) 239-256.

[90] U. Jeppsson, M.N. Pons, I. Nopens, J. Alex, J.B. Copp, C. Rosen, J.P. Steyer, P. A. Vanrolleghem, Benchmark simulation model no 2: general protocol and exploratory case studies, Wat. Sci. Tech. 56 (8) (2007) 67-78.

[91] I. Nopens, L. Benedetti, U. Jeppsson, M.-N. Pons, J. Alex, J.B. Copp, K.V. Gernaey, C. Rosen, J.-P. Steyer, P.A. Vanrolleghem, Benchmark Simulation Model No 2: finalisation of plant layout and default control strategy, Water Sci. Technol. 62 (2010) 1967.

[92] J. De Ketele, D. Davister, D. Ikumi, Applying performance indices in plantwide modelling for a comparative study of wastewater treatment plant operational strategies, Water Sa 44 (4) (2018) 539.

[93] I. Paleker, D.S. Ikumi, G.A. Ekama, A Plant-wide Evaluation of the Benchmark Simulation Model No.2P (BSM2P) for Wastewater Treatment Systems - Part 1: Model Introduction. WISA 2018, Cape Town, South Africa, June 2018, 2018.

[94] G.A. Ekama, Recent developments in biological nutrient removal, Water SA 41 (4) (2015) 515-524

[95] K. Solon, X. Flores-Alsina, C. Kazadi Mbamba, D. Ikumi, E.I.P. Volcke, C. Vaneeckhaute, G.A. Ekama, P.A. Vanrolleghem, D.J. Batstone, K.V. Gernaey, U. Jeppsson, Plant-wide modelling of phosphorus transformations in wastewater treatment systems: impacts of control and operational strategies, Water Res. 113 (2017) 97-110.

[96] A. Menniti, H. Andres, E. Bailey, L. Belia, K. Carson, S. Passaro, A. Pena-Tijerina, M. Reeves, O. Schraa, M. Seib, S. Snowling, Process modelling at Resource recovery utilities: lessons learned and missing tools, in: Proc. WRRmod2018, 1014 March 2018, Quebec, Canada, 2018, pp. 77-83.

[97] I. Lizarralde, T. Fernández-Arévalo, E. Ayesa, X. Flores-Alsina, U. Jeppsson, K. Solon, P. Vanrolleghem, C. Vaneeckhaute, D. Ikumi, C. Kazadi Mbamba, D. Batstone, P. Grau, From WWTP to WRRF: a new modelling framework, in: Proc. WRRmod2018, 10-14 March 2018, Quebec, Canada, 2018, pp. 149-157.

[98] B. Elduayen-Echave, I. Lizarralde, G.S. Larraona, E. Ayesa, P. Grau, A new massbased discretized population balance model for precipitation processes: application to struvite precipitation, Water Res. 155 (2019) 26-41.

[99] T. Fernández-Arévalo, I. Lizarralde, F. Fdz-Polanco, S.I. Pérez-Elvira, J. M. Garrido, S. Puig, M. Poch, P. Grau, E. Ayesa, Quantitative assessment of energy and resource recovery in wastewater treatment plants based on plant-wide simulations, Water Res. 118 (2017) 272-288.

[100] T. Fernández-Arévalo, B.S. Sabherwal, S. Arant, E. Belia, Experiences in the application of mathematical models in full scale WWTPs: the modelling from the perspective of applied research, in: Proc. WRRmod2018, 10-14 March 2018, Quebec, Canada., 2018.

[101] C. Brouckaert, A. Singh, W. Wu, Wastewater Treatment Plant Modelling for Capacity Estimation and Risk Assessment. WRC Report No. TT678/16, Water Research Commission, Pretoria, 2016.

[102] D. Le Maitre, H. Seyler, M. Holland, L. Smith-Adao, J. Nel, A. Maherry, K. Witthuser, Identification, Delineation and Importance of the Strategic Water Source Areas of South Africa, Lesotho and Swaziland for Surface Water and Groundwater. WRC Report No. TT 754/1/18, Water Research Commission, Pretoria, 2018.

[103] D. Silveti, K. Andersson, Challenges of governing off-grid "Productive" sanitation in peri-urban areas: comparison of case studies in Bolivia and South Africa, Sustainability 11 (12) (2019) 3468.

[104] L. Godfrey, S. Oelofse, Historical review of waste management and recycling in South Africa, Resources 6 (4) (2017) 57.

[105] A.G. Capodaglio, Integrated, decentralized wastewater management for resource recovery in rural and peri-urban areas, Resources 6 (2) (2017) 22.

[121] S.T.L. Harrison, B. Verster, S. Rumjeet, T. Raper, S. Rademeyer, M. JohnstoneRobertson, L. Mosters, Towards Wastewater Biorefineries: Integrated Bioreactor and Process Design for Combined Water Treatment and Resource Productivity. WRC Report 2380-1-17, 2016.

[122] A. Henricks, Review of the Fate of Waste Sludge Types and Other Products Towards Discovering How Best to Utilise the 'Resources' Recovered From Waste 
in Industrial Applications, Thesis, Water Research Group, Department of Civil
Engineering, University of Cape Town, Rondebosch, 7701, Cape Town, South Africa, 2019. 